\title{
What Is the Function of High Education---An Experiment in the Class of Law
}

\author{
Dr. jus. Yang Liü, a \\ ${ }^{1}$ School of Law, South China University of Technology, Guangzhou 510006, China \\ acnfaxue@126.com
}

Keywords: High Education; Law Education; Investigation; Universal Service

\begin{abstract}
To find out the function of high education on the students' minds and their changes, an experiment is executed in a class of law with 150 participants. In the experiment two investigations are implemented, one is accomplished before the course the other is accomplished after the course. The variety of the investigation results indicates the fact that high education can really give students the information to understand the society and the social economy, as the changes of certain required questions are proved dramatic. According to the result, the taught course might not change the minds of requested students, especially when they already have had some knowledge educated by the common senses. However, it is approved that the lessons learned in the class will be helpful for the students to make a more clear and objective choice. Therefore, this experiment would like to be regarded as the recognition of function and frontier of the high education.
\end{abstract}

\section{Introduction}

Reforms inside the sector of universal service are now the highlights in China. However, it is hardly for a common person to analyze the official documents or even to understand those key economics and legal terms. Judgments of the Chinese people on the issue of reform are fundamentally based on their common senses of living. But it is nonsense to dedicate that those common senses of living are wrong.

Traditional, high education has the function to illustrate the meaning of current policies to the students. Also it is interesting, what would be happened in those students after the course. It is to answer how the common senses of people will be changed by the education, and thereafter to indicate the function of high education.

\section{Objective and Design of the Experiment}

Objective of this experiment is to analyze the influence of law course on the students. It will focus on the changes of students' minds on the reform of the universal services when after they have taken part of the lessons. Also the experiment will illuminate the function of law education on understanding of the current policy.

In order to ensure the results of investigation, certain preparations are demanded, including the participants, the questionnaire and the knowledge that students will receive in the course.

The experiment includes two paper investigations, which are done before and after the lesson of economic law. During the course, the current policy of universal service reform will be theoretically explained and discussed. Student will then have some extra information given by the teacher to understand the historical development and background knowledge of the reforms. Additionally, the trends of reform and related international experiences will be also given to the students.

The investigation includes 12 questions, which is illustrated by the following table. 
1. Do you understand the meaning of universal service? YES/NO

2. Choose the correct sectors of universal service.

Post/Telecommunication/ Power/Water/Gas

3. Do you think, there is monopoly in the universal service YES/NO market?

4. Shall the monopoly be unbundled?

YES/NO

5. What are the problems in the market?

Monopoly/Information

Release/High

Price/Corruption

6. Can the private capital improve the industrial YES/NO efficiency?

7. What do you worry about, when private capital allowed Price Raise/Monopoly not in the universal service sector? Resolved/ Hurt of Public Interests/Collapse of Social Economy

8. Do you understand the meaning of natural monopoly? YES/NO

9. Will you choose the private suppliers?

YES/NO

10. Reasons of service chosen.

Enterprise Credibility/ Consumer Habit

/Price/Quality of Service

11. Duties of the Government.

Investment/Regulation/Sta ndard Setting/Price

Control

12. Is the time ready for the reforms?

YES/NO 


\section{Results of the Experiment}

Results of the experiment are indicated in the following table:

Table 2. Investigation Results

\begin{tabular}{|c|c|c|c|}
\hline \# & \% before the lessons & $\%$ after the lessons & change rate \\
\hline 1 & YES: 45 & YES: 100 & 55 \\
\hline 2 & Correct: 32 & Correct: 100 & 68 \\
\hline 3 & YES: 98 & YES: 100 & 2 \\
\hline 4 & YES: 82 & YES: 86 & 4 \\
\hline 5 & \#1:72, \#2:90, \#3:30, \#4:76 & \#1:45, \#2:100, \#3:17, \#4:19 & $\begin{array}{c}\# 1:-27, \# 2: 10, \# 3:-13 \text {, } \\
\text { \#4:-57 }\end{array}$ \\
\hline 6 & YES: 82 & YES: 54 & -28 \\
\hline 7 & \#1:32, \#2:79, \#3:45, \#4:47 & \#1:95, \#2:83, \#3:90, \#4:54 & $\# 1: 63, \# 2: 4, \# 3: 45, \# 4: 7$ \\
\hline 8 & YES: 3 & YES: 100 & 97 \\
\hline 9 & YES: 90 & YES: 63 & 17 \\
\hline 10 & $\begin{array}{c}\# 1: 100, \# 2: 90, \# 3: 96, \\
\# 4: 99\end{array}$ & $\begin{array}{c}\# 1: 100, \# 2: 89, \# 3: 93 \text {, } \\
\# 4: 100\end{array}$ & \#1:0, \#2:1, \#3:-3, \#4:1 \\
\hline 11 & $\begin{array}{c}\# 1: 80, \# 2: 95, \# 3: 100 \text {, } \\
\text { \#4:99 }\end{array}$ & $\begin{array}{c}\# 1: 65, \# 2: 100, \# 3: 80 \text {, } \\
\text { \#4:100 }\end{array}$ & \#1:-15, \#2:5, \#3:20, \#4: 1 \\
\hline 12 & YES: 100 & YES:100 & 0 \\
\hline 13 & YES: 80 & YES: 74 & -6 \\
\hline
\end{tabular}




\section{Analyses of the Results}

Since the purposes of investigated questions are multiple, it is necessarily to declare the intents of each question at first. Questions 1, 2 and 3 are to test the students on the basic knowledge of universal service, which will be illuminated in the course. It will show whether the students are ready for the investigation. Questions 4 and 5 are connected with the disadvantages of monopolized market, to let the student judge how to solve the market failure. Questions 6 and 7 concern about the market opening. Also it will indicate the individual market behavior of those investigated students. Questions 8 is about the fundamental information of monopoly regulation, it is the precondition to solve the questions 9 and 10, which are to discover the result of market reforms. Furthermore, the answer to question 10 will be probably based on the students' personal economic custom and habits. Question 11 is to testify the duties of government expected by the public, which will be mentioned in the class but not systematically taught. The final question will let the student freely estimate, whether the Chinese universal service sector should be opened to the private investments, or not. This question will be besides regarded as outcome of the course.

Results of this experiment are very interesting and will be probably important to the reform inside our market, which have also given some inspiring elements on understanding the function of high education.

\subsection{Function of High Education}

The high education serves the building of minds of mankind [1]. This is proved by the experiments, since the result of questions show that the fundamental knowledge on the issue of reform according to the Chinese laws has been absorbed by the students. Question 2, which is to indicate the standard of basic understanding of the universal services, and the rate change has illustrate that the students have established their knowledge structures and could use their knowledge to solve further questions [2].

Beyond the impacts on the students' knowledge structures and on their construction of related theories, what have been learned in the class can, however, not change the method of social economic behaviors of those students. Questions 7 and 10 have proved that the model of certain person in the social economy will not be easily changed, because the understanding of economic movements is not connected with market behaviors directly [3]. This is the border of high education [4], since the school is not created for the market but serves for the building of mankind.

\subsection{Usage of Knowledge}

Question 9 shows that the knowledge can be really used inside the market. Since the reform will change the model of price setting [5], the concern on the impacts of the reform will certainly change the minds of students. The more knowledge they have, the more understanding of the advantages of social market economy for the consumers will be remembered [6]. Further, after the course students can make correct answers to the detailed questions of the universal services, which they have even not heard before.

Question 7 indicates that the students have fund out the key elements of related reforms. Their minds on the shortages [7] of reforms are influenced by the course. The systematic teaching in the class has given the students those detailed disadvantages of free market [8]. Therefore, the education would certainly give more impacts on the social market movements and especially in the sector of law. Also question 9 shows that the students will give up their minds, since in the free market the price setting from the government will be vanished and thereafter prices of the universal services would even increase dramatically [9].

\subsection{Reflection of the Reform}

It is surprisingly interesting that certain common senses on the price of universal services are not wrong totally. For example, results of question 7 indicate that more than $83 \%$ of the students have no confidence on the reform to solve the problems incurred by monopolies. The result has even increased 4\% after the course. Since the experience and practice inside the US and Europe cannot be persuasive [10], results of the experiment is probably logic.

Then it comes to the question, what has the high education really given to the students? According to the investigation, students have received the systematic structures of related theories 
and also known the results of foreign practices. The knowledge might not change their minds on the function of government in the social economy, but the education will help them to make even more clearly choices, since they have known why they should make those chooses. And that is the real function of educations.

\section{Acknowledgments}

This research is financially supported by the National Social Science Foundation 国家社科基金 一般项目 (15BFX045) and Guangzhou Social Science Foundation 广州哲社 “十二五” 规划课题 (2015GZXY10) .

\section{References}

[1]. Kaisheng Lao: Pedagogic, Nankai University Publishing House, p.129.

[2]. Dehai Hu: Elementary Principles of Education, Gansu Educational Publishing House, p.89.

[3]. Yang Liu: Research of the Direct Power Purchase in China, Journal of China University of Geosciences, and 2013:14 (5) p.68.

[4]. Letian Zhang: Pedagogic, High Educational Publishing House, p.310.

[5]. Yang Liu: Electricity Price Regulation in the EU, Germany and China, AVM Munich 2013, p. 175.

[6]. Yang Liu: Cost Orientation of the Grid Charge - Legal Comparison of the EU, German and Chinese Energy Laws, AVM Munich, 2011, p. 52.

[7]. Lan Peng, On the Principles of Regulation System in China, International Journalists, 2007/11, p.16.

[8]. Yang Liu: Universal Service: Necessary Constitutional Provisions for the Reform in the Chinese Electricity Industry, US-China Law Review, 2015:5 (113) p.427.

[9]. Yang Liu: Online Finance: Regulatory Regime Reform in China, US-China Law Review, and 2015:4 (112) p.328.

[10]. Yang Liu: On the Possibility to Replace Ladder-type Price with Electricity Consumption Tax, Journal of Nanjing University of Technology, and 2013:12 (1) p.56. 